\title{
Nonylphenol and octylphenol in adipose tissue of women in Southern Spain
}

\author{
M.J. Lopez-Espinosa ${ }^{\mathrm{a}, \mathrm{b}}$, C. Freire ${ }^{\mathrm{a}}$, J.P. Arrebola ${ }^{\mathrm{a}}$, N. Navea ${ }^{\mathrm{a}, \mathrm{c}}, \mathrm{J}^{\text {. Taoufiki }}{ }^{\mathrm{c}, \mathrm{a}}$, M.F. Fernandez $^{\mathrm{a}}$, O. Ballesteros ${ }^{\mathrm{c}}$, \\ R. Prada ${ }^{a}$, N. Olea ${ }^{a, *}$ \\ a Laboratory of Medical Investigations, San Cecilio University Hospital, University of Granada, CIBER de Epidemiología y Salud Pública (CIBERESP), 18071 Granada, Spain \\ ${ }^{\mathrm{b}}$ Center for Research on Public Health (CSISP), Conselleria de Sanitat, Generalitat Valenciana, CIBER de Epidemiología y Salud Pública (CIBERESP), 46020 Valencia, Spain \\ ${ }^{\mathrm{c}}$ Department of Analytical Chemistry, Faculty of Sciences, University of Granada, 18071 Granada, Spain
}

\section{A R T I C L E I N F O}

\section{Article history:}

Received 15 January 2009

Received in revised form 27 March 2009

Accepted 27 March 2009

Available online 5 May 2009

\section{Keywords:}

Nonylphenol

Octylphenol

Endocrine disrupters

Adipose tissue

Spain

\begin{abstract}
A B S T R A C T
Alkylphenols (APs) and AP ethoxylates are environmental contaminants with endocrine disrupting activities in wildlife and humans. They have been largely used in industrial, agricultural, and domestic applications. Despite strong concerns about the consequences of human exposure to endocrine disrupters, little information is available on the presence in humans of compounds such as APs. The aim of the present study was to determine 4-nonylphenol (NP) and 4-octylphenol (OP) residues in adipose tissue of nonoccupationally exposed women living in Southern Spain. NP was detected in $100 \%(n=20 / 20)$ and OP in $23.5 \%(n=4 / 20)$ of samples, with median levels of 57 and $4.5 \mathrm{ng} \mathrm{g}^{-1}$ adipose tissue, respectively. Body mass index emerged as a determinant of exposure since it was associated with NP levels $(p=0.041)$. Adipose tissue NP and OP levels are similar to the few data previously published in other countries. This is the first report on NP and OP levels in a population in Southern Spain. Further research is needed to determine trends in human exposure to these compounds and to investigate their consequences.
\end{abstract}

(c) 2009 Elsevier Ltd. All rights reserved.

\section{Introduction}

Alkylphenol ethoxylates (APEs) have been the most widely used classes of non-ionic surfactants in industrial, agricultural, and domestic applications and are mainly introduced to the environment from wastewaters (Ying et al., 2002). Nonylphenol ethoxylates represent around $80 \%$ of APEs, while octylphenol ethoxylates make up most of the remaining 20\% (White et al., 1994). In sewage treatment plant (STP) effluents, APEs are degradated to shorter-chain and more resistant alkylphenols (APs), such as 4-nonylphenol (NP) and 4-octylphenol (OP). Many studies have demonstrated the ubiquity of APs in environmental media, especially in the aquatic environment (Ying et al., 2002). Thus, NP and OP have been detected in sediment, STP effluents, surface water, and drinking water in different countries (Ying et al., 2002; Soares et al., 2008). In Spain, studies have mainly focused on overexploited Mediterranean rivers (Sole et al., 2000; Petrovic et al., 2003; Lavado et al., 2004; Cespedes et al., 2005) and on the impact of these compounds on aquatic biota (Petrovic et al., 2002; Carballo et al., 2005).

Humans are largely exposed to APs by the intake of contaminated foods and drinking water. Both NP and OP have been detected in different foods (Guenther et al., 2002; Yang and Ding, 2005; Lu et al., 2007), and it has been suggested that NP and OP present in plastic containers and wrappings may migrate into foods and drink-

\footnotetext{
* Corresponding author. Tel.: +34 958242 864; fax: +34 958249953.

E-mail address: nolea@ugr.es (N. Olea).
}

ing water (Toyo'oka and Oshige, 2000; Loyo-Rosales et al., 2004). The Danish Environmental Agency proposed $5 \mu \mathrm{g} \mathrm{kg}^{-1}$ body weight as the Tolerable Daily Intake (TDI) of NP (Nielsen et al., 2000) and, although no TDI has been established for OP, a No Observed Adverse Effect Level (NOAEL) of $10 \mathrm{mg} \mathrm{kg}^{-1}$ body weight/d was reported by Tyl et al. (1999) based on a two-generation rat study. Other routes of human exposure to these compounds include contact with personal care products and detergents (Talmage, 1994) and the use of spermicides in contraceptives (Brooke et al., 2005). It has been suggested that humans are less exposed to APs than to other ED compounds, such as bisphenol A (BPA) (Calafat et al., 2005, 2008), which have a higher presence in the domestic environment (Wilson et al., 2007).

APs have long been reported to elicit estrogenic activity (Soto et al., 1991). Different in vitro (vitellogenin gene expression, Escreen and yeast-screen) and in vivo studies (rats and rainbow trout) conducted to assess their effects on endocrine pathways have demonstrated that APs can alter developmental and reproductive functions in animals and humans (reviewed by: Müller et al., 1998a; Bonefeld-Jorgensen et al., 2007). Resulting concerns about their impact on human health led to the prohibition by the European Union of APEs in all detergent applications by 2000 (European Commission-Joint Research Centre, 2002). NP ethoxylates have been replaced by other surfactants, mainly alcohol ethoxylates, in most European countries and in Canada and Japan. However, they are still used as an emulsifier in pesticides and as an antioxidant in plastics (European Commission-Joint Research Centre, 2002). 
Although much is known about the estrogenic effects of APs and their occurrence and fate in the environment, there have been few reports on their concentrations in human tissues (Ademollo et al., 2008; Calafat et al., 2005, 2008; Chen et al., 2005, 2008; Mao et al., 2004; Müller et al., 1998b; Smeds and Saukko, 2003; Tan and Mohd, 2003). The present study is part of an extensive characterization of the exposure of women in Southern Spain to environmental chemicals. Data have already been published on the presence in the same population of organochlorine (OC) pesticides (Cerrillo et al., 2006), polybrominated diphenyl ethers (PBDE), polybrominated biphenyls (PBB) (Fernandez et al., 2007a), BPA and chlorinated derivatives $\left(\mathrm{Cl}_{x} \mathrm{BPA}\right)$ (Fernandez et al., 2007b), polychlorinated biphenyls (PCBs) (Fernandez et al., 2008), and polychlorinated dibenzo-p-dioxins and dibenzofurans (PCDD/Fs) (LopezEspinosa et al., 2008). In order to expand these reference data for biomonitoring planning, the present study was designed to investigate the concentration of NP and OP residues in the adipose tissue of these women and to compare levels with other populations.

\section{Materials and methods}

\subsection{Subjects}

NP and OP were determined in 20 human adipose tissue samples collected from women undergoing surgery for malignant and benign diseases at the San Cecilio University Hospital of Granada (Spain) during 2003. All of these women lived in Granada. After signing informed consent, the women were interviewed by a trained interviewer using a structured questionnaire on their socio-demographic characteristics, reproductive history, and life-style factors. All women reported a mixed diet including meat and fish and no occupational exposure to AP compounds. The study was approved by the Ethics Committee of the San Cecilio University Hospital.

\subsection{Sample collection and storage}

Adipose tissues were placed into a glass vial on ice, coded, and frozen to $-86^{\circ} \mathrm{C}$, always within $30 \mathrm{~min}$ of being excised, and samples were stored at the same temperature at the Laboratory of Medical Investigations in the San Cecilio University Hospital of Granada (Spain) until their dispatch for analysis to the Department of Analytical Chemistry in the University of Granada, where NP and OP concentrations were determined.

\subsection{Reagents and standards}

All reagents were of analytical grade unless otherwise specified. Water (18.2 $\mathrm{M} \Omega \mathrm{cm}^{-1}$ ) was purified with a Milli-Q plus system (Millipore, Bedford, USA). Methanol, hexane, ethanol, ethyl acetate, and diethyl ether were supplied by Panreac (Barcelona, Spain). 4Nonylphenol (NP) and 4-octylphenol (OP) were supplied by Sigma-Aldrich (Madrid, Spain). Stock standard solutions (100 $\mathrm{mg} \mathrm{L}^{-1}$ ) of each chemical compound were prepared in $n$-hexane and stored in dark glass bottles at $4{ }^{\circ} \mathrm{C}$ until use, remaining stable for at least three months. These solutions were used to spike the adipose tissue samples. SPE cartridges $C_{18}$ AccuBONDII ODS- $C_{18}$ were supplied by Agilent Technologies, Waldbron, Germany). A mixture of $\mathrm{N}, \mathrm{O}$-bis(trimethylsilyl) triflouroacetamide (BSTFA) and trimethylchloro silane (TMCS) (99:1, v/v), supplied by Supelco (Bellefonte, PA, USA), was used as silylation reagent.

\subsection{Sample preparation, extraction, and derivatization}

Two hundred milligrams of adipose tissue were homogenized with $6 \mathrm{~mL}$ of $n$-hexane. Then, $2 \mathrm{~mL}$ of acetonitrile were added to the $n$-hexane solution. After shaking for $3 \mathrm{~min}$, the phase containing the acetonitrile was separated and dried under a gentle stream of nitrogen. Prior to the extraction, adipose tissue samples were spiked with bisphenol $\mathrm{F}$ (BPF) as internal standard. SPE cartridges were conditioned with $3 \mathrm{~mL}$ of diethylether, $3 \mathrm{~mL}$ of methanol, and $3 \mathrm{~mL}$ of deionized water on an SPE manifold at a rate of 1$2 \mathrm{~mL} \mathrm{~min}^{-1}$.

Sample extracts were resuspended using $15 \mathrm{~mL}$ of deionized water and passed through SPE cartridges at a flow rate of 1$2 \mathrm{~mL} \mathrm{~min}^{-1}$. SPE was carried out in a Supelco 12-port vacuum manifold connected to a Supelco vacuum tank and a vacuum pump. Then, cartridges were dried under vacuum for $20 \mathrm{~min}$. APs were eluted from sorbents with $3 \mathrm{~mL}$ of a mixture of diethyl ether/methanol $(9: 1 \mathrm{v} / \mathrm{v})$ at a flow rate of $1 \mathrm{~mL} \mathrm{~min}^{-1}$. Finally, eluents were evaporated to dryness under a stream of nitrogen, and $120 \mu \mathrm{L}$ of ethyl acetate and $30 \mu \mathrm{L}$ of BSTFA/TMCS $(1: 1, \mathrm{v} / \mathrm{v})$ were added to the reaction vial in order to resuspend the residue and carry out the derivatization. Next, vials were closed and heated at $60^{\circ} \mathrm{C}$ for $30 \mathrm{~min}$. Once the derivatization process was completed, $2 \mu \mathrm{L}$ of the reaction mixture was injected into the gas chromatographymass spectrometry (GC-MS) system.

\subsection{Apparatus: gas chromatographic-mass spectrometric analysis}

GC-MS analysis was performed using a 6890 Agilent (Agilent Technologies, Wilmington, USA) gas chromatograph with a 7683 series injector and a quadruple mass filter 5976 network mass selective detector (MSD) following a previously published method (Ballesteros et al., 2006). A ZB-5 MS Zebron capillary column (30 $\mathrm{m} \times 0.25 \mathrm{~mm}$ i.d.; $0.25 \mu \mathrm{m}$ film thickness) from Phenomenex (Torrance, CA, USA) was used for qualitative determinations, applying the selected ion-monitoring (SIM) mode for quantitative determinations. The injector port of the GC was set at $280^{\circ} \mathrm{C}$. Samples were automatically injected using the splitless-injection mode. The transfer line of the GC to the MS was set at $270{ }^{\circ} \mathrm{C}$, the electron impact (EI) ion source of the MS at $250^{\circ} \mathrm{C}$, and the electron impact (EI) ion source of the MS at $250^{\circ} \mathrm{C}$. The ionization energy was $70 \mathrm{eV}$. The GC oven temperature program was: initial temperature at $120^{\circ} \mathrm{C}$ for $2 \mathrm{~min}$ and then increased to $230^{\circ} \mathrm{C}$ at $30^{\circ} \mathrm{C} \mathrm{min}-1$ and maintained at $230{ }^{\circ} \mathrm{C}$ for $2 \mathrm{~min}$, then increased to $270{ }^{\circ} \mathrm{C}$ at $40{ }^{\circ} \mathrm{C} \mathrm{min}{ }^{-1}$ and maintained at $270{ }^{\circ} \mathrm{C}$ for $6 \mathrm{~min}$. The carrier gas was high-purity helium (99.999\%) with a constant flow of $1 \mathrm{~mL} \mathrm{~min}{ }^{-1}$. A solvent delay time of $4 \mathrm{~min}$ was used to protect the ion multiplier of the MS instrument from saturation. Fig. 1 shows a chromatogram of a standard mixture of NP, OP, and BPF in a spiked adipose tissue sample.

In SIM mode, the qualifier ions for NP and OP were $179 \mathrm{~m} / \mathrm{z}$ and $207 \mathrm{~m} / z$, respectively, corresponding to loss of OTMS group. The base peaks for NP and OP were 292 and $278 \mathrm{~m} / \mathrm{z}$, respectively, corresponding to molecular ion. Fragments 263 (OP) and 277 (NP) $\mathrm{m} / \mathrm{z}$

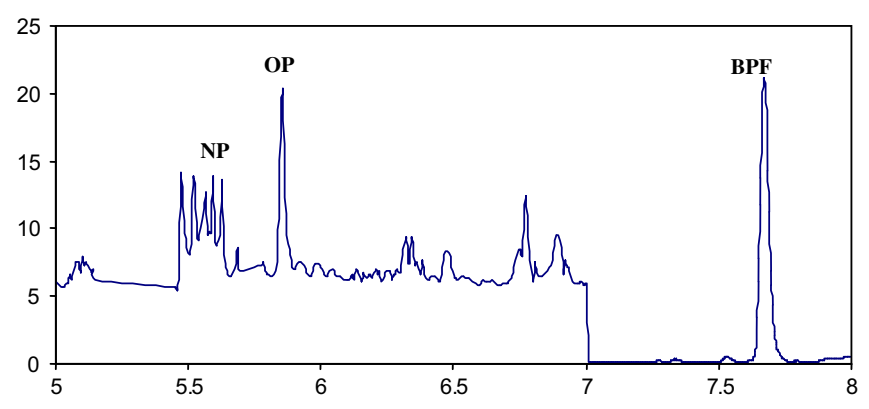

Fig. 1. Chromatogram of a standard mixture of 4-nonylphenol (NP), 4-octylphenol (OP), and bisphenol $\mathrm{F}(\mathrm{BPF})$ in a spiked adipose tissue sample. 
were also used, corresponding to loss of methyl group. The ions used for the internal standard, BPF, corresponded to $\mathrm{m} / \mathrm{z} 344$ (molecular ion), 329 (loss of methyl group) and 179 (loss of OTMS groups). Fig. 1 shows a chromatogram of a standard mixture of NP, $\mathrm{OP}$, and BPF in a spiked adipose tissue sample.

\subsection{Analytical performance}

Six concentrations were prepared for the calibration, applying the above extraction procedure (duplicate preparations and triplicate analyses of the central calibration sample). Calibration curves were constructed plotting the analyte/internal standard peak area ratio against the concentration of analyte. Linearity of the calibration graphs was tested using the lack-of-fit test, according to the Analytical Methods Committee (1994). Recoveries of tested compounds were $95-105 \%$ in all cases. Limits of detection (LOD) were 10.5 and $2.8 \mathrm{ng} \mathrm{g}^{-1}$ for NP and OP, respectively. Recoveries for internal standards were $70 \%$.

\subsection{Data analysis}

NP concentrations were transformed to a natural logarithm scale to improve the normal distribution of concentrations. Linear regression analyses for NP (dependent variable) were performed to examine its association with age (yrs) and body mass index (BMI) $\left(\mathrm{kg} \mathrm{m}^{-2}\right)$. Age and BMI were treated as continuous variables in the models. OP concentrations were not evaluated in the regression analysis because of the low frequency of their detection $(>$ LOD $=23.5 \%)$. Statistical analysis was performed using SPSS Version 15.0 statistical software (SPSS Inc., Chicago, IL).

\section{Results and discussion}

\subsection{Characteristics of study population}

The mean age (standard deviation [SD]) of this female population was 59.7 yrs (14.1), ranging from 24 to 81 yrs. Mean BMI (SD) was $31.8 \mathrm{~kg} \mathrm{~m}^{-2}(11.5)$, ranging from 19.1 to $65.0 \mathrm{~kg} \mathrm{~m}^{-2}$. This elevated mean BMI is consistent with previous reports (Fernandez et al., 2007a; Sotillo et al., 2007) of a higher BMI in women from Southern Spain than in women from other Spanish regions and central European countries. Thus, Sotillo et al. (2007) reported a mean BMI of 27.6 for $40-49-\mathrm{yr}$-old and $30.2 \mathrm{~kg} \mathrm{~m}^{-2}$ for $50-60-$ yr-old in women from the same region, similar to the mean of $32.4 \mathrm{~kg} \mathrm{~m}^{-2}$ for the over-40-yr-old in the present study. All women were Caucasians and none were occupationally exposed to APs.

\subsection{Levels of NP and OP in adipose tissue samples and comparison with other studies}

Similar to previous reports, the frequency of detection in adipose tissue samples of NP (100\%) was higher than that of OP (23.5\%) (Table 1) (Inoue et al., 2000; Tan and Mohd, 2003; Chen et al., 2005; Ademollo et al., 2008). NP was also present at higher concentrations (median $=57 \mathrm{ng} \mathrm{g}^{-1}$ adipose tissue) vs. OP, reach-

Table 1

Concentrations of 4-nonylphenol and 4-octylphenol ( $\mathrm{ng} \mathrm{g}^{-1}$ adipose tissue) in adipose tissue samples from women living in Southern Spain.

\begin{tabular}{llllll}
\hline & $n(\%)$ & $>$ LOD & & & \\
\cline { 3 - 6 } & & Mean (SD) & 25th & Median & 75th \\
\hline 4-Nonylphenol & $20 / 20(100)$ & $82(127)$ & 40 & 57 & 69 \\
4-Octylphenol & $4 / 20(23.5)$ & $5.5(2.1)$ & 4.2 & 4.5 & 7.7 \\
\hline
\end{tabular}

$n(\%)=$ Number of subjects (percentage of detection); LOD = limit of detection; $\mathrm{SD}=$ standard deviation. ing $567 \mathrm{ng} \mathrm{g}^{-1}$ adipose tissue in one sample (Fig. 2), which may be explained by the more frequent use of NP (European Commission-Joint Research Centre, 2002) and by a higher affinity of NP for lipid fractions (Ohta et al., 2002; Ademollo et al., 2008). Müller et al. (1998b) reported that NP is rapidly distributed into the lipid phase of the human body within $2 \mathrm{~h}$ of its oral administration. This lipophilicity may contribute to the bioaccumulation of NP observed in algae, fish, and aquatic birds living in or near a contaminated river (Ahel et al., 1993), which can also be attributed to the saturation of detoxification pathways from excessive exposure (Certa et al., 1996).

Although concentrations of NP and OP in different types of human sample have been reported in a few countries, their presence in adipose tissue is poorly documented (reviewed in Table 2). Moreover, comparisons are hampered by differences in study design (e.g., number of samples), country of origin, biological matrix, and the AP isomer studied. Median NP concentrations found in women from Southern Spain were similar to those reported by Müller et al. (1998b) in human adipose tissue from cadavers $(n=25)$ in Switzerland ( 37 vs. $57 \mathrm{ng} \mathrm{g}^{-1}$ adipose tissue in present study). In a Finnish study (Smeds and Saukko, 2003), OP was only detected in two adipose tissue samples $(n=2 / 13$ : 1.6 and $4.6 \mathrm{ng} \mathrm{g}^{-1}$ adipose tissue, respectively) at similar concentrations to those reported by Müller et al. (1998b) (range, 0.58$4.1 \mathrm{ng} \mathrm{g}^{-1}$ adipose tissue), and lower than OP concentrations determined in our study (range, 4.2-8.6 $\mathrm{ng} \mathrm{g}^{-1}$ adipose tissue in $4 / 20$ samples).

There is more information on AP concentrations in human blood, breast milk, and urine than on concentrations in adipose tissue (Table 2). Tan and Mohd (2003) reported that NP was the most frequent ED (86\%) in Malaysian cord blood $(n=180)$, finding 4- $n-$ $\mathrm{OP}$ and 4 -tert-OP at lower concentrations vs. NP in $53 \%$ and $17 \%$ of samples, respectively. In Taiwan, NP and OP were found in all plasma samples $(n=33)$ from a population occupationally exposed to these compounds (Chen et al., 2005), and NP was detected in $26 \%$ and $76 \%$ of umbilical cords from populations in Central

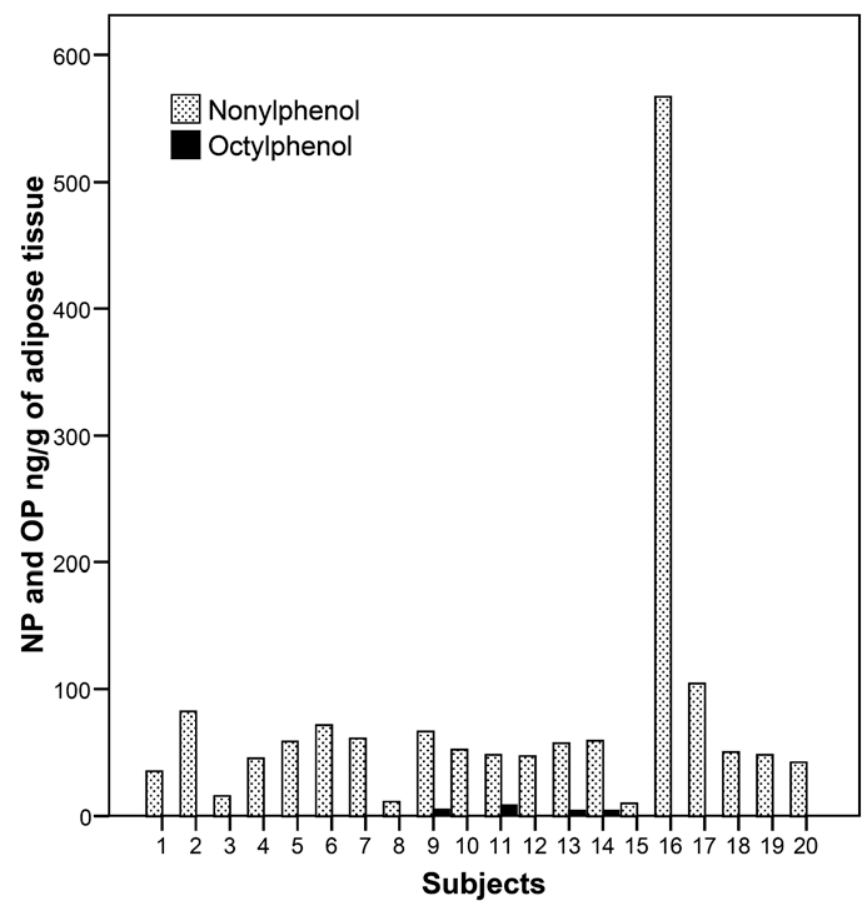

Fig. 2. Individual concentrations (ng g ${ }^{-1}$ adipose tissue) of 4-nonylphenol (NP) and 4-octylphenol (OP) in adipose tissue samples. 
Table 2

Reported concentrations of 4-nonylphenol (NP) and 4-octylphenol (OP) in human samples from different countries.

\begin{tabular}{|c|c|c|c|c|c|c|c|c|c|c|c|c|}
\hline \multirow[t]{2}{*}{ Study } & \multirow[t]{2}{*}{ Location } & \multirow[t]{2}{*}{ Study population } & \multirow[t]{2}{*}{ N } & \multirow[t]{2}{*}{ Sample } & \multicolumn{4}{|l|}{ NP } & \multicolumn{4}{|l|}{$\mathrm{OP}$} \\
\hline & & & & & $\%>$ LOD & Median & Min & Max & $\%>$ LOD & Median & Min & Max \\
\hline Present study ${ }^{\mathrm{a}}$ & Southern Spain & Women, 24-81 yrs & 20 & Adipose tissue & 100 & 57 & 10 & 567 & 23.5 & 4.5 & nd & 8.6 \\
\hline Müller et al. $(1998 b)^{a}$ & Switzerland & 15 Males, 10 females, $3-100$ yrs & 25 & Adipose tissue (cadavers) & 100 & 37 & 19.8 & 84.4 & - & - & 0.58 & 4.07 \\
\hline Smeds and Saukko (2003) ${ }^{\mathrm{a}}$ & Finland & 7 Males, 6 females, $43-90$ yrs & 13 & Adipose tissue (cadavers) & - & - & - & - & 15.4 & $1.6 / 4.6$ & - & - \\
\hline Inoue et al. $(2000)^{b}$ & Japan $^{\mathrm{c}}$ & Healthy people & 3 & Blood (plasma) & - & - & 0.5 & 1.0 & - & - & nd & $<0.25$ \\
\hline Tan and Mohd $(2003)^{\mathrm{b}}$ & Malaysia & Women & 180 & Cord blood (plasma) & 86 & - & nd & 15.2 & $17^{\mathrm{g}}$ & - & nd & 1.15 \\
\hline Kawaguchi et al. $(2004)^{\mathrm{b}}$ & $J^{J a p a n}{ }^{\mathrm{c}}$ & Healthy people, $24-25$ yrs & 3 & Blood (plasma) & 100 & - & 0.2 & 0.3 & 100 & - & 0.1 & 0.2 \\
\hline Chen et al. (2005) & Taiwan & Housekeepers & 33 & Blood (plasma) & 100 & $53(40)^{d}$ & 12.1 & 285 & $100^{\mathrm{g}}$ & $16(2.8)^{\mathrm{d}}$ & 12.68 & 23.9 \\
\hline \multirow[t]{3}{*}{ Liu et al. $(2006)^{\mathrm{b}}$} & China $^{c}$ & Healthy people & 10 & Blood (serum) & - & - & - & - & 20 & 0.2 & 0.2 & 0.2 \\
\hline & & Women, Central Taiwan & 124 & Cord blood (plasma) & 26 & 0.9 & nd & 182 & - & - & - & - \\
\hline & & Women, Northern Taiwan & 50 & Cord blood (plasma) & 76 & 42 & nd & 211 & - & - & - & - \\
\hline \multirow[t]{2}{*}{ Chen et al. $(2008)^{a}$} & Taiwan & Expectant women, $18-40$ yrs & 42 & Blood (plasma) & 52 & 5.7 & nd & 268 & - & - & - & - \\
\hline & & Women, $18-40$ yrs & 42 & Cord blood (plasma) & 52 & 2.9 & nd & 100 & - & - & - & - \\
\hline Otaka et al. $(2003)^{a}$ & Japan $^{\mathrm{c}}$ & Women & 3 & Breast milk & 100 & - & 0.65 & 1.4 & - & - & - & - \\
\hline Ye et al. (2006) $)^{\mathrm{b}}$ & US & Women & 20 & Breast milk & - & - & - & - & $25^{\mathrm{g}}$ & $2.7^{\mathrm{e}}$ & nd & 7.6 \\
\hline Ademollo et al. $(2008)^{b}$ & Italy & Women & 10 & Breast milk & 100 & 34 & 13.4 & 56.3 & 70 & 0.12 & nd & 0.2 \\
\hline Kuklenyik et al. (2003) & US & People painting their homes & 30 & Urine & 0 & nd & - & - & $35^{\mathrm{g}}$ & - & 0.4 & 13.9 \\
\hline Kawaguchi et al. (2004) b & $J^{a p a n}{ }^{c}$ & Healthy people, $22-24$ yrs & 5 & Urine & 0 & nd & - & - & 0 & nd & - & - \\
\hline \multirow[t]{2}{*}{ Mao et al. $(2004)^{\mathrm{b}}$} & China & Males, $21-29$ yrs & 10 & Urine & 50 & $0.38(0.8)^{\mathrm{d}}$ & nd & 2.3 & - & - & - & - \\
\hline & & Females, $21-29$ yrs & 10 & Urine & 70 & $0.05(0.05)^{\mathrm{d}}$ & nd & 0.14 & - & - & - & - \\
\hline \multirow[t]{2}{*}{ Calafat et al. (2005) ${ }^{\mathrm{b}}$} & US & $\geqslant 6$ yrs (NHANES) & 371 & Urine & 51 & $<0.1(\text { nd }-1.6)^{f}$ & - & - & - & - & - & - \\
\hline & & Housekeepers & 29 & Urine & 97 & $6.2(4.8)^{\mathrm{d}}$ & nd & 36.7 & $83^{\mathrm{g}}$ & $6.5(8.7)^{\mathrm{d}}$ & nd & 71.5 \\
\hline \multirow[t]{2}{*}{ Chen et al. $(2005)^{\mathrm{b}}$} & Taiwan & Textile workers, pre-shift & 40 & Urine & 90 & $21(18)^{d}$ & nd & 71.9 & $50^{\mathrm{g}}$ & $1.4(1.7)^{\mathrm{d}}$ & nd & 7.02 \\
\hline & & Textile workers, post-shift & 40 & Urine & - & $38(46)^{d}$ & - & - & - & $2.1(2.5)^{d}$ & - & - \\
\hline Kawaguchi et al. $(2005)^{\mathrm{b}}$ & Japan $^{\mathrm{c}}$ & Healthy people & 5 & Urine & 100 & - & 1.04 & 2.0 & $20^{\mathrm{g}}$ & - & nd & 0.05 \\
\hline Kawaguchi et al. $(2006)^{b}$ & $J^{J} a n^{c}$ & Healthy people, $22-25$ yrs & 6 & Urine & $100^{\mathrm{h}}$ & - & $<1.1$ & 2.1 & - & - & - & - \\
\hline Calafat et al. $(2008)^{\mathrm{b}}$ & US & $\geqslant 6$ yrs (NHANES) & 2,517 & Urine & - & - & - & - & $57^{\mathrm{g}}$ & $0.3(\text { nd }-0.4)^{\mathrm{f}}$ & - & - \\
\hline
\end{tabular}

$N$ = sample size; LOD = limit of detection; nd = not detected; NHANES = The National Health and Nutrition Examination Survey.

a $\mathrm{ng} / \mathrm{g}$.

Methodological studies.

d Mean (standard deviation).

e Mean.

${ }^{\mathrm{f}}$ Median (95\% confidence interval).

g tertiary-OP.

NP-glucuronide. 
( $n=124)$ and North $(n=50)$ Taiwan, with higher concentrations in residents of metropolitan areas (Chen et al., 2008). Trace levels of APs in human blood have been detected in various Japanese and Chinese studies (Inoue et al., 2000; Kawaguchi et al., 2004; Liu et al., 2006). Reports on breast milk NP levels have ranged from $0.65-1.4 \mathrm{ng} \mathrm{g}^{-1}$ in Japan $(n=3)$ (Otaka et al., 2003) to 13.4$56.3 \mathrm{ng} \mathrm{mL}^{-1}$ in Italy $(n=10)$ (Ademollo et al., 2008), with OP levels ranging from non-detected (nd) to $0.2 \mathrm{ng} \mathrm{mL}^{-1}$ in Italy (Ademollo et al., 2008) and from nd to7.6 $\mathrm{ng} \mathrm{mL}^{-1}$ for tertiary-OP (tert-OP) in the USA $(n=20)$ (Ye et al., 2006).

Urinary AP levels were measured in two large NHANES (The National Health and Nutrition Examination Survey) reports, finding NP in $51 \%$ and tert-OP in $57 \%$ of US individuals (Calafat et al., 2005, 2008), with higher concentrations of tert-OP (median $=0.3 \mathrm{ng} \mathrm{mL}^{-1}$ ) than of NP. Lower OP concentrations and similar NP levels to US findings were reported in Japanese studies, although the number of samples was very small (Kawaguchi et al., 2004, 2005, 2006). Urinary OP (range $=0.4-14 \mathrm{ng} \mathrm{mL}^{-1}$ ) but not NP was detected in people painting their homes in US (Kuklenyik et al., 2003). A Taiwanese study (Chen et al., 2005) of textile workers exposed to NP and OP found significantly higher urinary AP levels at the end of the shift (mean $\mathrm{NP}=38 \mathrm{ng} \mathrm{mL}^{-1}$ ) compared with pre-shift samples $\left(21 \mathrm{ng} \mathrm{mL}^{-1}\right)$. Higher urinary NP levels were found in Chinese males $(n=10$; mean $=0.38$ $\mathrm{ng} \mathrm{\textrm {mL } ^ { - 1 }}$ ) than females $\left(n=10\right.$; mean $\left.=0.05 \mu \mathrm{g} \mathrm{L}^{-1}\right)$, although the frequency of detection was higher in the latter (70 vs. 50\%) (Mao et al., 2004). Calafat et al. (2008) also found small sex differences in urinary OP levels (median $=0.3$ and $0.2 \mathrm{ng} \mathrm{mL}^{-1}$ in men and women, respectively).

\subsection{Associations of NP and OP levels with age and BMI}

We found a significant and negative association between NP concentration and BMI $(\beta=0.05 ; 95 \% \mathrm{CI}=0.01,0.09 ; p=0.033$; $R^{2}=0.27$, which remained significant after controlling for women's age $\left(\beta=0.05 ; 95 \% \mathrm{CI}=0.02,0.09 ; p=0.041 ; R^{2}=0.27\right.$ ). Previous studies of these women showed non-significant associations between body fat content and concentrations of PCBs, PCDD/Fs, PBDE/PBBs, and BPA in adipose tissue (Fernandez et al., 2007a,b, 2008; Lopez-Espinosa et al., 2008). Interestingly, the most obese woman $\left(65 \mathrm{~kg} \mathrm{~m}^{-2}\right)$ in this series had the highest adipose tissue levels of NP as well as of PCBs (Fernandez et al., 2008), PCDD/Fs (Lopez-Espinosa et al., 2008), PBBs (Fernandez et al., 2007a), and $\mathrm{Cl}_{2}$ BPA (Fernandez et al., 2008).

NP levels were not associated with age $(\beta=-0.01$; $95 \% \mathrm{CI}=-0.04,0.03 ; p=0.81$ ), as reported for PBDEs and PBBs (Fernandez et al., 2007a) and in contrast to findings for other persistent and fat soluble compounds (Fernandez et al., 2007b, 2008; LopezEspinosa et al., 2008), although the lack of significance may be attributable to the small sample size. Finally, due to the low frequency of detection of OP $(n=4 / 20)$, its association with age and BMI was not evaluated.

A major route of exposure to APs may be diet. Ten years ago, Müller et al. (1998a) estimated that the daily oral intake of NP by non-occupationally exposed people was less than $0.16 \mathrm{mg} \mathrm{d}^{-1}$. More recently, Guenther et al. (2002), Thomson et al. (2003), and Lu et al. (2007) reported the presence of OP and especially NP in various foods in Germany, New Zealand, and Taiwan and estimated the daily adult intake of NP to be $7.5,3.3$, and $28 \mu \mathrm{g} \mathrm{d}^{-1}$, respectively. In the German diet survey, NP concentrations in food samples ranged from 0.1 to $19.4 \mu \mathrm{g} \mathrm{kg}^{-1}$, regardless of their fat content (Guenther et al., 2002). The above variations in AP intake may be attributable to differences in food habits, although many of the food samples purchased in local supermarkets were internationally marketed products.

\section{Conclusions}

$\mathrm{NP}$ was detected in $100 \%$ (median $=57 \mathrm{ng} \mathrm{g}^{-1}$ adipose tissue, $n=20 / 20$ ) and OP in 23.5\% (median $=4.5 \mathrm{ng} \mathrm{g}^{-1}, n=4 / 20$ ) of the present samples at similar levels to the very few reports on their presence in adipose tissue. Although APs have a lower affinity for lipid fractions in comparison to other ED compounds, adipose tissue is a suitable matrix to determine their concentrations. In addition, there is an extensive body of data on the exposure of these women to different groups of persistent and bioaccumulative compounds as measured in adipose tissue, which may better reflect past exposure and may therefore offer a chronological marker of exposure.

\section{Acknowledgements}

We thank Richard Davies for editorial assistance. This research was supported by Grants from the Consejería de Salud de la Junta de Andalucía (SAS 07/0133), the Spanish Ministry of Health (FIS 07/ 0252), Spanish Ministry of Science and Innovation (Programa Juan de la Cierva-FSE y Programa FPU), and the EU Commission (CONTAMED FP7-ENV-212502).

\section{References}

Ademollo, N., Ferrara, F., Delise, M., Fabietti, F., Funari, E., 2008. Nonylphenol and octylphenol in human breast milk. Environ. Int. 34, 984-987.

Ahel, M., McEvoy, J., Giger, W., 1993. Bioaccumulation of the lipophilic metabolites of nonionic surfactants in freshwater organisms. Environ. Pollut. 79, 243-248.

Analytical Methods Committee, 1994. Is my calibration linear? Analyst 119, $2363-$ 2366.

Ballesteros, O., Zafra, A., Navalon, A., Vilchez, J.L., 2006. Sensitive gas chromatographic-mass spectrometric method for the determination of phthalate esters, alkylphenols, bisphenol $\mathrm{A}$ and their chlorinated derivatives in wastewater samples. J. Chromatogr. A 1121, 154-162.

Bonefeld-Jorgensen, E.C., Long, M., Hofmeister, M.V., Vinggaard, A.M., 2007. Endocrine-disrupting potential of bisphenol A, bisphenol A dimethacrylate, 4$n$-nonylphenol, and 4-n-octylphenol in vitro: new data and a brief review. Environ. Health Perspect 115, 69-76.

Brooke, D., Crookes, M., Johnson, I., Mitchell, R., Watts, C., 2005. Prioritisation of Alkylphenols for Environmental Risk Assessment. National Centre for Ecotoxicology and Hazardous Substances, Environment Agency.Bristol, UK.

Calafat, A.M., Kuklenyik, Z., Reidy, J.A., Caudill, S.P., Ekong, J., Needham, L.L., 2005. Urinary concentrations of bisphenol A and 4-nonylphenol in a human reference population. Environ. Health Perspect 113, 391-395.

Calafat, A.M., Ye, X., Wong, L.Y., Reidy, J.A., Needham, L.L., 2008. Exposure of the U.S. population to bisphenol A and 4-tertiary-octylphenol: 2003-2004. Environ. Health Perspect 116, 39-44.

Carballo, M., Aguayo, S., de la, T.A., Munoz, M.J., 2005. Plasma vitellogenin levels and gonadal morphology of wild carp (Cyprinus carpio L.) in a receiving rivers downstream of sewage treatment plants. Sci. Total Environ. 341, 71-79.

Cerrillo, I., Olea-Serrano, M.F., Ibarluzea, J., Exposito, J., Torne, P., Laguna, J., Pedraza, V., Olea, N., 2006. Environmental and lifestyle factors for organochlorine exposure among women living in Southern Spain. Chemosphere 62, 19171924

Certa, H., Fedtke, N., Wiegand, H.J., Muller, A.M., Bolt, H.M., 1996. Toxicokinetics of p-tert-octylphenol in male Wistar rats. Arch. Toxicol. 71, 112-122.

Cespedes, R., Lacorte, S., Raldua, D., Ginebreda, A., Barcelo, D., Pina, B., 2005. Distribution of endocrine disruptors in the Llobregat River basin (Catalonia, NE Spain). Chemosphere 61, 1710-1719.

Chen, M.L., Chang, C.C., Shen, Y.J., Hung, J.H., Guo, B.R., Chuang, H.Y., Mao, I.F., 2008. Quantification of prenatal exposure and maternal-fetal transfer of nonylphenol. Chemosphere 73, S239-S245.

Chen, M.L., Lee, W.P., Chung, H.Y., Guo, B.R., Mao, I.F., 2005. Biomonitoring of alkylphenols exposure for textile and housekeeping workers. Int. J. Environ. Anal. Chem. 85, 335-347.

European Commission-Joint Research Centre, 2002. European Union Risk Assessment Report 4-Nonylphenol (branched) and Nonylphenol. EUR 20387 EN. Office for Official Journal of the European Communities, Institute for Health and Consumer Protection, European Chemicals Bureau, Luxembourg, p. 230.

Fernandez, M.F., Araque, P., Kiviranta, H., Molina-Molina, J.M., Rantakokko, P., Laine, O., Vartiainen, T., Olea, N., 2007a. PBDEs and PBBs in the adipose tissue of women from Spain. Chemosphere 66, 377-383.

Fernandez, M.F., Arrebola, J.P., Taoufiki, J., Navalon, A., Ballesteros, O., Pulgar, R., Vilchez, J.L., Olea, N., 2007b. Bisphenol-A and chlorinated derivatives in adipose tissue of women. Reprod. Toxicol. 24, 259-264.

Fernandez, M.F., Kiviranta, H., Molina-Molina, J.M., Laine, O., Lopez-Espinosa, M.J., Vartiainen, T., Olea, N., 2008. Polychlorinated biphenyls (PCBs) and hydroxyPCBs in adipose tissue of women in Southeast Spain. Chemosphere 71, 11961205. 
Guenther, K., Heinke, V., Thiele, B., Kleist, E., Prast, H., Raecker, T., 2002. Endocrine disrupting nonylphenols are ubiquitous in food. Environ. Sci. Technol. 36, 16761680.

Inoue, K., Yoshimura, Y., Makino, T., Nakazawa, H., 2000. Determination of 4nonylphenol and 4-octylphenol in human blood samples by high-performance liquid chromatography with multi-electrode electrochemical coulometric-array detection. Analyst 125, 1959-1961.

Kawaguchi, M., Ishii, Y., Sakui, N., Okanouchi, N., Ito, R., Inoue, K., Saito, K., Nakazawa, H., 2004. Stir bar sorptive extraction with in situ derivatization and thermal desorption-gas chromatography-mass spectrometry in the multi-shot mode for determination of estrogens in river water samples. J. Chromatogr. A 1049, 1-8.

Kawaguchi, M., Ito, R., Hayatsu, Y., Nakata, H., Sakui, N., Okanouchi, N., Saito, K., Yokota, H., Izumi, S., Makino, T., Nakazawa, H., 2006. Stir bar sorptive extraction with in situ de-conjugation and thermal desorption gas chromatography-mass spectrometry for measurement of 4-nonylphenol glucuronide in human urine sample. J. Pharmaceut. Biomed. Anal. 40, 82-87.

Kawaguchi, M., Sakui, N., Okanouchi, N., Ito, R., Saito, K., Izumi, S., Makino, T., Nakazawa, H., 2005. Stir bar sorptive extraction with in situ derivatization and thermal desorption-gas chromatography-mass spectrometry for measurement of phenolic xenoestrogens in human urine samples. J. Chromatogr. B, Analyt. Technol. Biomed. Life Sci. 820, 49-57.

Kuklenyik, Z., Ekong, J., Cutchins, C.D., Needham, L.L., Calafat, A.M., 2003. Simultaneous measurement of urinary bisphenol A and alkylphenols by automated solid-phase extractive derivatization gas chromatography/mass spectrometry. Anal. Chem. 75, 6820-6825.

Lavado, R., Thibaut, R., Raldua, D., Martin, R., Porte, C., 2004. First evidence of endocrine disruption in feral carp from the Ebro River. Toxicol. Appl. Pharmacol. 196, 247-257.

Liu, M., Hashi, Y., Pan, F., Yao, J., Song, G., Lin, J.M., 2006. Automated on-line liquid chromatography-photodiode array-mass spectrometry method with dilution line for the determination of bisphenol $\mathrm{A}$ and 4-octylphenol in serum. J. Chromatogr. A 1133, 142-148.

Lopez-Espinosa, M.J., Kiviranta, H., Araque, P., Ruokojarvi, P., Molina-Molina, J.M., Fernandez, M.F., Vartiainen, T., Olea, N., 2008. Dioxins in adipose tissue of women in Southern Spain. Chemosphere 73, 967-971.

Loyo-Rosales, J.E., Rosales-Rivera, G.C., Lynch, A.M., Rice, C.P., Torrents, A., 2004 Migration of nonylphenol from plastic containers to water and a milk surrogate. J. Agric. Food Chem. 52, 2016-2020.

Lu, Y.Y., Chen, M.L., Sung, F.C., Wang, P.S., Mao, I.F., 2007. Daily intake of 4nonylphenol in Taiwanese. Environ. Int. 33, 903-910.

Mao, L., Sun, C., Zhang, H., Li, Y., Wu, D., 2004. Determination of environmental estrogens in human urine by high performance liquid chromatography after fluorescent derivatization with p-nitrobenzoyl chloride. Anal. Chim. Acta 522 241-246.

Müller, S., Schmid, P., Schlatter, C., 1998a. Evaluation of the estrogenic potency of nonylphenol in non-occupationally exposed humans. Environ. Toxicol. Pharmacol. 6, 27-33.

Müller, S., Schmid, P., Schlatter, C., 1998b. Pharmacokinetic behavior of 4nonylphenol in humans. Environ. Toxicol. Pharmacol. 5, 257-265.

Nielsen, E., Østergaard, G., Ladefoged, O., Jelnes, O., Jelnes, J.E., 2000. Toxicological Evaluation and Limit Values for Nonylphenol, Nonylphenol Ethoxylates, Tricresyl, Phosphates and Benzoic acid. Environmental Project. Danish Environmental Protection Agency, Copenaghen, DK, p. 43.

Ohta, S., Ishizuka, D., Nishimura, H., Nakao, T., Aozasa, O., Shimidzu, Y., Ochiai, F. Kida, T., Nishi, M., Miyata, H., 2002. Comparison of polybrominated diphenyl ethers in fish, vegetables, and meats and levels in human milk of nursing women in Japan. Chemosphere 46, 689-696.
Otaka, H., Yasuhara, A., Morita, M., 2003. Determination of bisphenol A and 4nonylphenol in human milk using alkaline digestion and cleanup by solid-phase extraction. Anal. Sci. 19, 1663-1666.

Petrovic, M., Barcelo, D., Diaz, A., Ventura, F., 2003. Low nanogram per liter determination of halogenated nonylphenols, nonylphenol carboxylates, and their non-halogenated precursors in water and sludge by liquid chromatography electrospray tandem mass spectrometry. J. Am. Soc. Mass Spectrom. 14, 516-527.

Petrovic, M., Sole, M., Lopez de Alda, M.J., Barcelo, D., 2002. Endocrine disruptors in sewage treatment plants, receiving river waters, and sediments: integration of chemical analysis and biological effects on feral carp. Environ. Toxicol. Chem. 21, 2146-2156.

Smeds, A., Saukko, P., 2003. Brominated flame retardants and phenolic endocrine disrupters in Finnish human adipose tissue. Chemosphere 53, 1123-1130.

Soares, A., Guieysse, B., Jefferson, B., Cartmell, E., Lester, J.N., 2008. Nonylphenol in the environment: a critical review on occurrence, fate, toxicity and treatment in wastewaters. Environ. Int. 34, 1033-1049.

Sole, M., Lopez de Alda, M.J., Castillo, M., Porte, C., Ladergaard-Pedersen, K., Barcelo D., 2000. Estrogenicity determination in sewage treatment plants and surface waters from the Catalonian area (NE Spain). Environ. Sci. Technol. 34, 50765083.

Sotillo, C., Lopez-Jurado, M., Aranda, P., Lopez-Frias, M., Sanchez, C., Llopis, J., 2007. Body composition in an adult population in southern Spain: influence of lifestyle factors. Int. J. Vitam. Nutr. Res. 77, 406-414.

Soto, A.M., Justicia, H., Wray, J.W., Sonnenschein, C., 1991. p-Nonyl-phenol: an estrogenic xenobiotic released from "modified" polystyrene. Environ. Health Perspect 92, 167-173.

Talmage, S.S., 1994. Environmental and Human Safety of Major Surfactants; Alcohol Ethoxylates and Alkylphenol Ethoxylates, the Soap and Detergent association. Lewis Publisher.

Tan, B., Mohd, M., 2003. Analysis of selected pesticides and alkylphenols in human cord blood by gas chromatograph-mass spectrometer. Talanta 61, 385391.

Thomson, B.M., Cressey, P.J., Shaw, I.C., 2003. Dietary exposure to xenoestrogens in New Zealand. J. Environ. Monit. 5, 229-235.

Toyo'oka, T., Oshige, Y., 2000. Determination of alkylphenols in mineral wate contained in PET bottles by liquid chromatography with coulometric detection. Anal. Sci. 16, 1071-1076

Tyl, R.W., Myers, C.B., Marr, M.C., Brine, D.R., Fail, P.A., Seely, J.C., Van Miller, J.P., 1999. Two-generation reproduction study with para-tert-octylphenol in rats. Regulat. Toxicol. Pharmacol. 30, 81-95.

White, R., Jobling, S., Hoare, S.A., Sumpter, J.P., Parker, M.G., 1994. Environmentally persistent alkylphenolic compounds are estrogenic. Endocrinology 135, 175182.

Wilson, N.K., Chuang, J.C., Morgan, M.K., Lordo, R.A., Sheldon, L.S., 2007. An observational study of the potential exposures of preschool children to pentachlorophenol, bisphenol-A, and nonylphenol at home and daycare. Environ. Res. 103, 9-20.

Yang, D.K., Ding, W.H., 2005. Determination of alkylphenolic residues in fresh fruits and vegetables by extractive steam distillation and gas chromatography-mass spectrometry. J. Chromatogr. A 1088, 200-204.

Ye, X., Kuklenyik, Z., Needham, L.L., Calafat, A.M., 2006. Measuring environmenta phenols and chlorinated organic chemicals in breast milk using automated online column-switching-high performance liquid chromatography-isotope dilution tandem mass spectrometry. J. Chromatogr. B, Analyt. Technol. Biomed. Life Sci. 831, 110-115.

Ying, G.G., Williams, B., Kookana, R., 2002. Environmental fate of alkylphenols and alkylphenol ethoxylates - a review. Environ. Int. 28, 215-226. 